\title{
Participation challenges of Emirati and Saudi students at US universities
}

\author{
Al Murshidi, Ghadah $\triangle$ \\ United Arab Emirates University, UAE (G_almurshidi@uaeu.ac.ae)

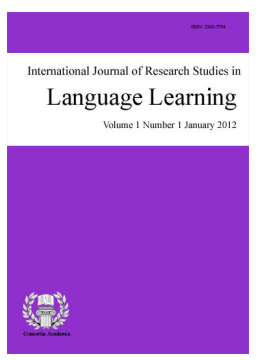

Accepted: 14 December 2013

ISSN: 2243-7754 Online ISSN: 2243-7762

OPEN ACCESS

\section{Abstract}

The purposes of this study are to explore speaking, presentation, participation and socialization challenges in their classrooms. The theoretical orientations framing this study are language and academic socialization, and language adjustment, etc. The study combined quantitative and qualitative strategies involving surveying 250 students followed by interviewing three Emirati and three Saudi students. The interview responses were coded to themes. Content analysis is used to interpret the data. Some major findings of the survey are that Emirati students "rarely" feel that native English speaking students are more competent than they are in classes. Emirati and Saudi students feel "less comfortable" participating in large group discussions and completing presentations assignments, and "comfortable" participating in small group discussion in classes. However, the interview results indicate several factors that influence the cultural adjustment of international students such as language differences and skills (Klineberg \& Hull, 1979). As a Saudi student; Khalifah, indicated his experience with silence upon arriving in the US language preparation program due to language differences. He is fluent in his native language "Arabic" and trying to improve his English proficiency. The study implies that Emirati and Saudi students' sponsors should prepare students to learn new skills and adjust to the educational system of the American universities, which is different from that in their native countries. This study is important for retention programs and for educators and policymakers in the UAE, Saudi Arabia and US.

Keywords: academic socialization; language socialization; language adjustment; international education; participation 


\section{Participation challenges of Emirati and Saudi students at US universities}

\section{Introduction}

The Emirati and Saudi students' participation in US universities have not had extensive research, thus this focus deserves scrutiny and has value for higher education through creation of a "global lens." The study is crucial for illuminating the situations students from UAE and Saudi Arabia and other international students who lack certain social and linguistic capital necessary to successfully function in their disciplines, and in broader communities outside higher education. The study's value accrues to sponsors of international students, particularly for its potential to expose fault lines in higher education and study-abroad preparatory programs that are inattentive to the needs of first-time international students attending American Universities. The study becomes extremely important for retention programs and for educators and policymakers in the UAE and Saudi Arabia, US and elsewhere.

The study analyzes my story and the stories of Emirati and Saudi students' participation in their classroom in the United States Universities. The purpose of this study is to explore what their challenges regard their speaking, presentation and socialization in their classrooms. Focusing on an exploratory comparative case study of students from the United Arabs Emirates and Saudi Arabia is particularly significant in investigating the context of higher education programs in which the issue of institutional transition may be just as important linguistic and cultural influences. Specifically, this comparative case study investigates Emirati and Saudi students' academic experiences in their academic discourses as they transition through US universities, to identify important variables which cause Emirati and Saudi students' participation challenges: What are the challenges? How do students cope with the challenges?

\subsection{Autobiographical context of the study}

I recognize that a study of academic challenges is not new but every story is unique. My journey and struggles to acquire academic speaking skills to become a legitimate participant in an academic discipline are complex and long term. The initial struggles began with my decision to study English in my native country, the United Arab Emirates (UAE). Some of these struggles are both linguistically and socio-culturally based. Evidently, as a Muslim woman from the UAE, my primary language is Arabic, and English is my second language. Although my studies of the English language began at an early age, several issues in future years would impact the way I speak and communicate in "academic speak." This process was primarily influenced by my teachers and mentors, who relied mostly on grammar translation as opposed to communicative language teaching, speaking and listening. Collectively, these processes, totally unknown to me, accounted for the ways in which, in later years, I would communicate in an academic discipline in a US university context.

This situation, though not necessarily accurately perceived at the time, equally accounted for the many challenges I encountered during my first year at a US university setting. Even though I spoke English reasonably well, these communicative challenges provoked an internal struggle between my self-esteem and the quest to remedy the situation, and often not finding a method of oral expression that was acceptable to my peers and teachers. Because of these dilemmas and contradictions, I have determined to do something about it: to investigate the little known complexity of this phenomenon, particularly in the Gulf region.

The underlying assumption of my predicament is that my bachelor's degree preparation in the UAE did not prepare me adequately to tackle the new situation in American graduate education. I should note further that English language classes were not taught in a vacuum. They were taught among other subjects that happened to be predominantly taught in Arabic. Such differences between Arabic and English are markedly dissimilar in the ways in which learners are socialized into these two distinct language spheres. Being an insider of the Emirati 
community facilitates my understanding of the Emirati and Saudi students' divergent experiences as a result of different educational systems, college preparation, and teachers.

The United Arab Emirates and its education System - The United Arab Emirates (UAE) with a total area of 83,600 sq. km., which is sited at the Southern tip of the Arabian Gulf. The Gulf region surrounding countries are Saudi Arabia, Qatar and Sultanate of Oman. It has a tropical desert climate with very little or no rainfall. It encompasses united seven emirates: Abu Dhabi, Dubai, Sharjah, Ajman, Ummal-Quwain, Ras al-Khaimah, and Fujairah and governed by a federal system instituted on the 2 December 1971. Abu Dhabi city is the capital of UAE.

The discovery of crude oil and its commercial production in the UAE established a new economic position that was reflected in the availability of substantial financial resources and investment in the country development. Over the past thirty years, the UAE developed economically as a result of the oil and gas discovery and tourism. The population has been increased and influenced by the rapid development. Various cultural groups are settled in these seven emirates with the nationals such as Arabs, Iranians, Filipinos, Indians, Europeans and Americans. They are known as expatriates which are approximately 70 percent of the population.

The education system of the UAE is new comparing to other countries. It is divided into public and private sectors. The public schools are funded by the government which all nationals have access to them. The public schools' curriculum is influenced by the Islamic religion and Arabic language (Gaad, Arif, \& Scott, 2006). The classes in public schools are single gender classes (Gaad, 2001). The majority of expatriates go to private schools to meet their religious, cultural and education needs. The language of instruction in most private schools is English, which some Emirati parents send their children to improve their English. Based on the analysis of the UAE education system, some researchers found that the public education system is ineffective despite the government funding (Shaw et al., 1995). In the past, the dropout rate and repetition rates are higher in the UAE than any other gulf states (Muhanna, 1990). The attrition rates in the public schools are critical (Badri, 1998).

Emirati students come to the US universities and they have studied their high school or the bachelor or Master degree in their native countries which the educational system, the language of instruction, culture ,are different than the US culture and universities. The majority of Emirati students sponsored by the UAE Ministry of higher Education to study in the US, UK, Canada, Australia, and other counties around the world. Its mission is to keep abreast of the progress and developments in the international teaching and training methods; to strive to improve performance and acquire further experiences, where the instructional outputs will represent a key component of the overall development of the community, through which future leaders are well prepared and developed so as to satisfy the UAE needs for academically qualified national manpower (Students' Guide for scholarship, 2012).

Other sponsors of the Emirati students are the United Arab Emirates University, Abu Dhabi Education Council, Abu Dhabi Investment Authority, Dubai Police, and Presidential Scholarship Program. Most of these students attend orientations in their institutions before traveling to the US. These orientations are mostly focus on student financial benefits, medical issues, travel, reimbursements, housing, banking, driving in the US, safety tips, universities accreditation, diplomas authentication, student visas, etc. Most the sponsors offer a whole year for admission and language preparation programs such as TOEFL, IELTS, GRE, GMAT, etc. The focus of these preparation programs is preparing the students' linguistically and academically more than socially.

The Saudi Arabia and its education System - Saudi Arabia traces its roots back to the earliest civilizations of the Arabian Peninsula. Over the centuries, the peninsula has played a significant role in history as an ancient trade center and as the birthplace of Islam, one of the world's major monotheistic religions. Since King Abdulaziz Al-Saud established the modern Kingdom of Saudi Arabia in 1932, its transformation has been astonishing. In a few short decades, the Kingdom has turned itself from a desert nation to a modern, sophisticated state and a major player on the international stage (Information Office of the Royal Embassy of Saudi Arabia in Washington, DC, 2012). 
The Saudi educational policy objectives are to ensure the affectivity of the Saudi students' education that meets the religious, economic and social needs of the Saudi Arabia and to decrease illiteracy among Saudi population. The Ministry of Education sets overall regulations for the Saudi Arabia educational system that encompasses public and private sectors. Moreover, it oversees special education for the handicapped. The Ministry of Higher Education was established in 1975 to apply the Saudi Arabia higher education policy .The Ministry of Higher Education supervises scholarships of Saudi students studying abroad, coordinates international inter-university relations and oversees the educational and cultural mission offices in various countries (Saudi Arabia Cultural mission to the US, 2012).

The Saudi Arabian Cultural Mission (SACM) is to apply Saudi national educational and training policies to provide Saudi Arabia with qualified individuals capable of achieving Saudi Arabia objectives of progress. Saudi Arabia tries to provide Saudi students with the best possible educational opportunities at the best educational institutions in the USA. The Cultural division in the Saudi Arabia Embassy in Washington, DC tires to support Saudi students academically and financially so that they may concentrate on achieving their academic goals. Moreover, the cultural division tries to collect and publicize information that reflects Saudi culture, tradition, and heritage through their active participation in academic, cultural, and social activities in the US (The Saudi Arabian Cultural Mission, 2012).

The issue of untrained teachers affects the quality of Saudi students' learning and education over the past 40 years (Cross, 1995). The Ministry of Education has recruited non-Saudi EFL teachers, especially from Arab countries, who are not well trained (Al-Awad, 2002).The English teachers are not qualified to undertake such a task. They lack subject knowledge, language proficiency, and competence in second/foreign language teaching methodology (Al-Ahaydib, 1986; Zaid, 1993). The Ministry of Education has tried to improve and update English language curricula since 1991 (Sheshsha, 1982; Zaid, 1993).

\section{Literature review}

Acquisition focuses on linguistic knowledge; cognitive orientations perceive acquisition as information processing, and thereby separate learners' minds from their environments. However, participation is the perception that learning the second language is a process of gaining membership in a new community (Sfrad, 1998, cited in Pavlenko \& Lantof, 2000). Sfrad (1998) indicates that the narratives of second language learners emphasize the significance of participation in new communities and exemplify the ongoing difficulties these learners face.

Scholars define academic socialization as a process in which students undergo a social and cultural transformation from one cultural and linguistic context in another context or language in order to become legitimate or proficient participants in a given academic discipline (Belcher, 1994; Canagarajah, 2002; Casanave, 1995, 2002; Hirvela \& Belcher 2001; Ivanic, 1998; Ivanic \& Camps, 2001; Prior 1995). Language socialization describes the use of language to mediate social interaction in academics (e.g., Bizzell, 1992; Eckert \& McConnell-Ginet, 1998; Lave \& Wenger, 1991, 1998). Socialization occurs when bilingual or multilingual students learn the language of academia through their interaction with students more proficient in the language and who have more cultural knowledge of the target academic communities' capabilities for mentoring or learning the appropriate uses of language, ideologies, values, and identities of community members (Duff, in press). The process of second language socialization is critical for Gulf students who are characteristically second language students (Duff, 2003; Moore, 1999; Poole, 1992; Watson-Gegeo, 1992; Willett, 1995).

Second language socialization studies, drawing from the framework of language socialization, have emphasized diverse students' participation in different academic communities. The overarching finding of these studies indicates that although international students have access to the host community's discourses, they encountered complex situations in the socialization process due to a variety of factors, such as lack of engagement in the second language community's culture or the disconnection between students' native cultures 
and the schools' cultures, which eventually impacted achievement. For example, Emirati and Saudi students face difficulties in English speaking as other Arab students (Abdul Haq, 1982; Harrison, Prator, \& Tucker, 1975; Abbad, 1988). Also, Jordanian students learn English in their native countries which the official language is Arabic as the Gulf region countries. The opportunities of learning and practicing English naturally are very limited to communicating with tourists. The students see no significance in communicating in English in their native countries where the surroundings are mostly communicating in the native language, Arabic. English might not be used beyond their classroom (Syed, 2003).

The most obvious problems that hinder the progress of Arab students at University level may be attributed to the "inadequate mastery of the four language skills; namely listening, speaking, reading and writing" (Sulieman, 1983, p. 129). The Arabs students face difficulty in communicating in the target language at the university level (Sulieman, 1983). The native language, Arabic, interference is not the only factor of the Arab students' challenges, but the teaching and language process also contribute to their challenges in English (Rababah, 2002).

Language adjustment refers to the newcomers' acquiring a second language during their social interaction with the hosting people (Yang \& Clum, 1994). The emphasis on English is significant because difficulties with English language are often an attribution for one cause of stress experienced by international students. Yang and Clum (1994) stated that among many factors that affect international students' adjustments, language proficiency is the most important determent. Barrat and Huba (as cited in Malkinckrodt et al., 2008) also found that a high level of language proficiency leads to international students' academic success and adjustment to the host culture. This proficiency enhances international students' performances in classes and feelings of comfort when participating in discussions. Skill with language also facilitates socialization with American peers, who play an important role in international students' cultural adjustments (Mallinckrodt et al., 2008). Mallinckrodt et al. (2008) contended that international students who speak English fluently tend to be less embarrassed and less self-conscious about their accents or ethnic backgrounds, and thus exhibit higher levels of self-esteem and better adjustment.

Learning is a socially constructed process that students experience with peers and instructors while participating in academics. The Morita (2000) study of classroom activities examined graduate students' academic socialization through presentations in the classroom. This study indicated that non-native Englishspeaking students' linguistic, socio-cultural and psychological difficulties tend to impact their engagement in the classroom activities. Students' lack of confidence, knowledge, social skills, and critical thinking, all challenge their interactions. Negotiating conflicting identities and shifting epistemic stances influence the students' academic performance and self-worth. Students view themselves as novices or experts in their social interaction when they display some cultural knowledge. As observed by Morita, during the dynamic process of academic socialization, students begin to gain competence and membership in their new academic communities.

International students seek support from their co-nationals. They might need to reduce their interaction and dependence on their co-nationals, and in turn increase their interaction with hosts in order to acquire the skills necessary to adjust successfully to the new environment. Restricting their interaction with hosts will only inhibit learning the new language, values, and norms of the culture and will reinforce feelings of alienation (Aresberg \& Niehoff, 1964; Garraty \& Adams, 1959; Gullarhorn \& Gullarhorn, 1966; Kang, 1972; Lundstedt, 1963). Essentially, interaction with members outside the co-nationals group is important for their integration (Kim, 1987). Kagan and Cohen (1990) found that students who had close American friends were more likely to have an easier shift to the new culture than those without the same relationships.

\section{Research design and method}

The focus of this research is a comparative study of Saudi and Emirati students who transition into US universities. The main purpose of this study is exploring the Emirati and Saudi students' participation challenges in their classrooms. This is a mixed-method research design that combines quantitative and qualitative strategies 
involving surveying 250 students followed by interviews. Research criterion-based purpose sampling (Patton, 2002) frame of this study includes selection of students from different US universities who are Gulf-region natives. The selection of the sample follows the criteria: 1) all participants are native speakers of Arabic; 2) all participants have resided in the US for a period no longer than seven years.

For the quantitative data, the researcher created a database to store the results from the Quartlics website. The Statistical Package for Social Sciences (SPSS) 16.0 was used to conduct statistical analyses. The researcher calculated and identified the mean, range, and standard deviation scores for all these categories using SPSS software. Also, inferential statistical tests included $t$-test was used. The present qualitative strategy provided an opportunity for the voices of Emirati and Saudi students to emerge. It gave a descriptive analysis of six Emirati and Saudi students' experiences. The interviews were coded to themes for analysis (thematic analysis). Content analysis was used to interpret the data.

To ensure the content and face validity of the developed questionnaire for this study, higher education experts reviewed the questionnaire items to judge content to assure content validity (Gable \& Wolf, 1993; Trochim \& Donnelly, 2007). American and Gulf region higher education experts, including one American university professor and one Gulf-region university professor, a higher education practitioner, two Emirati students, and two Saudi students receive copies of the items developed for the survey. Based upon the opinions of the experts and others, the items deemed most appropriate for determining Emirati and Saudi students' participation experiences become the items in the questionnaire (Stone, 1978).

Along with the questionnaire developed in the earlier step are directions for responding to the instrument, and guidelines for an administrative format. Subsequently, the instrument, written in English undergoes translation into Arabic. A review of the translation by a panel of three Gulf-region doctoral candidates in the United States determining the translation's appropriateness (van de Vijver \& Leung, 1997) is the final step prior to distribution to participants for gather data collection. Member checks is employed (Merriam, 2002) in this study assures validity. Also, after transcribing the interviews, two doctoral students, one from UAE and one from Saudi Arabia received copies of the Arabic and English versions to check the translations for validity.

All study participants were Emirati and Saudi students who are enrolled in US universities. Therefore, dependability for this study can be seen in the selection of participants who were qualified to address the issues related to the research problem. In addition, changes that occurred throughout the research process are documented and reported to the IRB. The concept of Triangulation in this study uses the strategy of two different research methods (survey questionnaire and interviews).

This study is part of a larger study that examines communication process of Emirati and Saudi students in the US Universities. The selection of the students who are from the UAE and Saudi Arabia to be my participants and conduct this comparative study is based on several factors:

1. The UAE and Saudi Arabia are different in size. Saudi Arabia is the largest country in the Gulf region

2. Saudi Arabia dominates the culture of the Gulf. It has a lot of influence over the Gulf States than the UAE

3. Saudi Arabia has strong ties relationships with the US than the UAE

4. Emirati and Saudi students have maintained the highest enrollments in US universities (e.g., Penn State University) among the Gulf region students over the years

5. Measuring the decision and preference of the Emirati and Saudi higher education

\subsection{Profiles of Interview Participants}

For the purposes of familiarity, this section constitutes a narrative describing the Emirati and Saudi 
participants. These introductory vignettes provide insight into the educational backgrounds and preparation of the Emirati and Saudi students before travelling to the US and their current educational situations in US universities. The introduction provides a context for the perspectives of the participants and characterizations their backgrounds from various aspects: country, gender, past educational backgrounds, parental influence in learning English, influence of schooling types (public or private) in learning English, and English language preparation programs in the students' native countries or the US Using these contexts should convey the individuality of each student and the connections between the students that influenced the students' experiences in US universities. Tables 1 and 2 list the six interviewees and their pseudonyms, genders, age, and degrees.

\section{Table 1}

The Emirati Interviewees

\begin{tabular}{llll}
\hline Student & Gender & Age & Degree \\
\hline Hoor & Female & 23 & Bachelor in genetics \\
Zayed & Male & 21 & Bachelor in nuclear engineering \\
Khaled & Male & 24 & Bachelor in architecture engineering \\
\hline
\end{tabular}

Table 2

The Saudi Interviewees

\begin{tabular}{llll}
\hline Student & Gender & Age & \multicolumn{1}{c}{ Degree / Program / Major } \\
\hline Sheikha & Female & 19 & Bachelor in engineering \\
Khalifah & Male & 25 & Master in risk management \\
Hassan & Male & 31 & the Intensive English Communication Program (IECP) \\
\hline
\end{tabular}

\subsection{The Emirati Participants}

\section{Participant 1: Hoor}

Hoor is an Emirati female student, 23 years old, holds a bachelor's degree from the Pennsylvania State University with a major in biology, specifically, genetics. She is completing her third year in college after spending one year at the language institute in New York. She has no previous experience in any European country. High school education occurred in Abu Dhabi, UAE and moved among schools. Study of English began in a private kindergarten, continued through private elementary schools and in public middle and high schools. Studying English required little effort with not time spent preparing for English classes, and the materials for English in grades seven through twelve were repetitive. Memorizing grammatical rules was unnecessary from previous natural knowledge (e.g., verb, subject, object, etc.) without explicit instruction.

In private school, she learned sentence construction sentences without specifying sentence constituents, such as subject, verb, and object. She feels public schools confused her learning English, especially grammar, but was fluent in English upon entering public school. Her mother encouraged learning English, by bringing English books home. Despite being Arab, her mother's first language is English due to education in non-Arabic schools and living in predominately in Kenya and gaining English education there, which prompted a focus on English at home. Her mother speaks and reads Arabic but does not write Arabic. She learned Urdu instead of Arabic because Kenya did not have Arabic schools. Hoor knows only Arabic, English and little Spanish, would like to speak Urdu. To have a one year language preparation is obligatory by sponsorship (The Scholarship Coordination Office -SCO) regulations to get the TOEFL score. This language preparation program did not prepare Hoor for the TOEFL or SAT.

The teachers at the language institute did not prepare the students for the required admissions' tests for US universities. She felt that this year was a waste of her time. A TOEFL preparation program would be a better choice, and completed one in the summer 2009 in the UAE, resulting in the required TOEFL score for admission. 
Hoor stated that the benefit from the language preparation program writing ability development, with grammar instruction similar to that in the UAE schools. Her speaking and listening did not develop as well, but writing was progressed, especially academic writing which is different from that taught in high school. Hoor stated that in the UAE high school writing was just paragraph constructions, with a maximum length of one page. However, the teachers in the language institute taught writing multiple-page manuscripts from a single topic and emphasized thinking in English rather than Arabic. The language institute philosophy encouraged students to speak fluently, in immediate English, without trying to translate from Arabic to English.

\section{Participant 2: Zayed}

Zayed is an Emirati student from Fujairah. Zayed scholarship is from UAE ENIC Petroleum Company, and he is an undergraduate student at the Pennsylvania State University. As a sophomore, his major is nuclear and mechanical engineering. He completed one year of a language preparation program at Georgia Technology center. He transferred from public schools to the higher technology high school in seventh grade and remained there through grade twelve. He had challenges in the higher technology high school, including difficulty constructing sentences and correct grammar. Students from different cities were in the same school such as Diba, Korfakkan, and Fujairah. He had placement test based on the students' language proficiency and their grades in the test. He stated that the placement test was easy for him because he used to attend some English preparation programs during summer. Also, they had a mathematic test. He started with A level. Other students mentioned that the test was difficult because they depend only on the public schools.

The language which he learnt in the higher technology school is similar to what he has studied in the language preparation program in Georgia. Most Emirati students were in level 5 to 6 in the language preparation program in Georgia because we were prepared in the higher technology school. The higher technology schools are different than the public schools. For example, some majors are specified for the students. Zayed's major was engineering science. He took some engineering courses which were different scientific courses. All subjects were taught in English. Only Arabic and Islamic studies were in Arabic language which were only once a week. The curriculum is a little bit different than the public schools. For instance, Zayed had studied Calculus II which is also similar to a course at Penn State University. This was advantage for him. The physics and chemistry were similar to the public school but it was in English. The English was easy in Level A, but when the higher technology school realized the easiness of teaching materials for students, revised materials changed and became more complicated. Teaching focused on academic writing instead of writing paragraphs as in the public schools. When he came to the English preparation program in Georgia, the teachers were surprised at Emirati students' English language proficiency. The higher technology school facilitated Zayed's English language and academic studies in his engineering major at Georgia Technology University and Pennsylvania State University. Zayed stated that some Emirati parents prohibit their sons from attending the higher technology schools even though their sons' desires to do so. The higher technology schools annually select forty to fifty Emirati students from each emirate, totaling one or two hundred students, to study abroad to learn English and attend engineering colleges during summer. For instance, Zayed went to Scotland and his nephew went to France.

After graduating from the higher technology school, students apply for scholarships and attend career fairs, which introduce students to appropriate careers to pursue. Zayed applied to US universities during the language preparation year, which ENIC Petroleum Company requested. He had a supervisor who helped him in application process and applied for him for Georgia technology Centre. He scored 80 in TOEFL which was an admission requirement for Pennsylvania State University. He is taking 21 credits each semester because he is a double major student and to graduate on time. He thinks that the double major is not that difficult because he is trying to keep his GPA high and take the required courses. The double major will open other possibilities of careers. He has a contract with ENIC to return graduation and work with ENIC He is planning to apply for a Master degree immediately after his bachelor's degree. 


\section{Participant 3: Khaled}

Khaled is a 24-year old male Emirati student, married and living with his wife and daughter. He is a bachelor's degree student at Penn State University and he will graduate in 2012. His major is architectural engineering, sponsored by the (The Scholarship Coordination Office -SCO). His language preparation year occurred in Utah, and he sat for the TOEFL tests many times and achieved a score of 89, which meets requirements for admission to Pennsylvania State University. He attended various English preparation classes at Penn State and ESL classes such as ESL 15, English 202 which is for Engineering students, and CAS 100 A that focuses on speaking and presentation. In his last year, he is planning attend CAS $202 \mathrm{C}$ that focuses on writing. He studied at all male, public high schools in Abu Dhabi.

\subsection{The Saudi participants}

\section{Participant 1: Sheikha}

Sheikha is a 19-year old Saudi student from Al Qatif; near the UAE and with similar culture. She received her scholarship from the Saudi Aramco petroleum company. The first time when she came to Pennsylvania State University, she was with her father. She visited some European countries such as Britain for five weeks. Her sister was there but she was working most the time in the hospital as part of her internship and Medical graduate study. She went to Britain when she was 16 years old to take a summer course to improve her English. Her family was paying the tuition for the language preparation program. ARAMCOramco assigned her to attend a one year language preparation program in Al Thahran in Saudi Arabia, and then sent her to the US At Aramco, female and male teachers instructed Sheikha for TOEFL, SAT and other tests. Sheikha did not attend public school in Saudi Arabia where Arabic is the language of instruction, and only female teachers taught female students.

Most ARAMCO students come directly to US universities without attending language preparation programs in the US. For students who do not meet all the American universities' requirements, ARAMCO sends them to British universities. When Sheikha came to Penn State University, she gained one year advanced placement because she had already completed courses, chemistry and calculus with good grades, equivalent to US universities' requirements. Most teachers in ARAMCO were foreigners or Arabs but with American nationalities who lived abroad. ARAMCO, one of the largest petroleum companies in the world, has a branch in Huston, London and Hong Kong. This company's origin is in Saudi Arabia beginning with King Abdullah's contract with American Petroleum Company. Then, the King bought the company, and Aramco began a program of sponsoring Saudi female students. English in the high school was really poor, and not all teachers were prepared to teach English.

In Sheikha's case, English teachers were proficient. Sheikha thinks that teaching English in high school is like teaching them to be only tourists, and not a language which will have continued to use in colleges. Teaching English was very basic, using traditional methods and focused only on grammar. Fatima's family prepared her to learn English while she was a child by sending her to summer language preparation programs. In Fatima's home, her family members speak English because they lived abroad for 17 years before returning to Saudi Arabia. At this year, Sheikha was born in Saudi Arabia. Her father studied medicine in Britain and practices in Saudi Arabia. At ARAMCO, Sheikha was in higher a level studying for TOEFL, but other lower level students studied IELTS. She was in a higher English level so she took courses but teachers were not that serious. She passed TOEFL the first time. The TOEFL course was for taking notes. The language preparation program for the students who were studying for IELTS was extensive. For three classes a day, these students practice IELTS continually and take samples of IELTS tests. However, for TOEFL preparation, students had no extensive preparation because Sheikha had English basics. They were using Academic English textbooks. Her teacher was not following some textbooks. For instance, Sheikha was discussing politics and current events in some countries in their class. Her major will be engineering. 
Al Murshidi, G.

Participant 2: Khalifah

Khalifah is a 25year old, single, Saudi student from Al Qasim, and he lives with his brother who is studying in the US Khalifah is pursuing a master's degree in risk management after completing a bachelor's degree in Business Management in the US Saudi Higher Education provided his scholarships for his bachelor and master degrees. He has spent six years for his education, a year for language preparation four years for his bachelor degree, plus one year toward his master's degree. His first time to the US was a week before Ramadan. He stayed with American family. In Saudi Arabia, he studied in public school and his English ability was limited. After a language preparation program for eight months, he completed the IELTS and gained admission to Pennsylvania State University.

\section{Participant 3: Hassan}

Hassan is a 31-year old Saudi student from Al Qasim, and currently attends the Intensive English Communication Program (IECP) at the Pennsylvania State University. He arrived in America on the 6th of April 2010. He has been in the US almost a year and a half. He studied Lock Haven University in Pennsylvania, and after almost 4 months, transferred to Penn State. He did not benefit from the Lock Haven language institute and stated that the teachers are discriminators. The university is small and the language institute focuses only on business. They care only about money and not improving the students' learning. They do not care about the student. Then, he transferred to the language institute at Penn State in August 2010 which varies in its administration, curriculum development and teachers each semester.

All his education has been in Arabic, including his master's degree, for which his thesis was written in Arabic but the abstract in English. He stated that, currently, his university in Saudi Arabia has changed to an English system. Hassan thinks the Saudi universities' levels are the best among the universities in the Arabic countries. Internationally, Saudi Arabia has only Abdullah king university. It might be the only one that has graduate programs in Saudi Arabia. The study is in English, and it has international students from America, Japan, Korea, China, almost from all countries, not only from Saudi Arabia. He is planning to study for a doctorate in microbiology.

\section{Results}

This section presents some of the findings of the questionnaire and the interviews. The main three results that the questionnaire indicates are as followed:

\subsection{Linguistics Challenges}

When Emirati and Saudi students expressed their feelings that native English speaking students are more competent in classes, the highest number of Emirati students $(34.4 \%)$ and Saudi students $(36.4 \%)(\mathrm{M}=2.45$, $\mathrm{SD}=1.04)$ indicated "rarely" feeling that native English speakers are more competent. The next highest percentage of Emirati students (31.2\%) indicated "never" feeling native English speakers are more competent in class. However, the second highest percentage of Saudi students $(27.3 \%)$ indicated feeling "occasionally" native English speakers are more competent in class (See Table 3 and Figure 1). Differences between Saudi and Emirati students are significant for identifying their feeling that the native speakers' students are more competent than them in their classes. Saudi students reported that they "rarely" feel that the native speakers' students are more competent than them in their classes as did Emirati students $(\mathrm{M}=2.17, \mathrm{SD}=1.03)$. This difference was significant $(p=.04)$ and represents a small effect difference (Cohen $d=.27)$ (See Table 4).

When Emirati and Saudi students responded to queries involving their linguistic deficits' preventing participation in classroom, the highest number of Emirati students (34.4\%) and Saudi students (45.1\%) indicated that their linguistics deficits "rarely" prevent classroom participation. A few Emirati students (1.1\%) indicated that linguistics deficits "always" prevented class participation; however, $3.3 \%$ of Saudi students indicated 
linguistics deficits "very often" prevented participation (See Table 5 and Figure 2). Differences between Saudi and Emirati students are insignificant regarding linguistics deficits preventing classroom participation. Emirati students reported rare influence from linguistic deficits for classroom participation $(\mathrm{M}=2.17 ; \mathrm{SD}=.97)$ as did Saudi students $(\mathrm{M}=2.34 ; \mathrm{SD}=1.01)$ (See Table 6).

Table 3

Item 1 (Native speakers' competence) Responses by Percentage

Do you feel that the native speakers' students are more competent than you in your classes?

\begin{tabular}{ccccccc}
\hline \multicolumn{2}{c}{ Option } & Never & Rarely & Occasionally & Very Often & Always \\
\hline Country & UAE & $31.2 \%$ & $34.4 \%$ & $20.4 \%$ & $14.0 \%$ & $.0 \%$ \\
& SA & $19.0 \%$ & $36.4 \%$ & $27.3 \%$ & $14.9 \%$ & $2.5 \%$ \\
& UAE \& SA & $24.8 \%$ & $37.2 \%$ & $23.5 \%$ & $13.2 \%$ & $1.3 \%$ \\
\hline
\end{tabular}

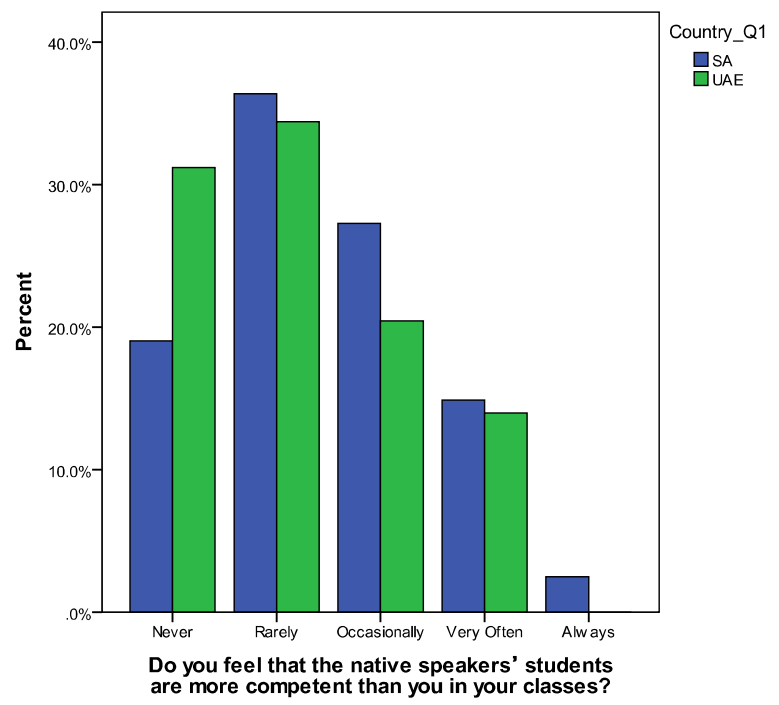

Figure 1. Item 1(Native speakers' competence) Responses by percentage

Table 4

Independent T-test Results for Item 1(Native speakers' competence)

\begin{tabular}{|c|c|c|c|c|c|c|c|}
\hline Item & Country & $n$ & Mean & $S D$ & $t$ & $p$ & Cohen's d \\
\hline Do you feel that native & SA & 122 & 2.45 & 1.04 & 1.98 & 0.04 & 0.27 \\
\hline $\begin{array}{l}\text { English-speaking } \\
\text { students are more } \\
\text { competent than you in } \\
\text { your classes? }\end{array}$ & UAE & 93 & 2.17 & 1.03 & & & \\
\hline
\end{tabular}

\section{Table 5}

Item 2(Linguistic abilities and classroom participation) Responses by Percentage In class, my linguistic abilities prevent me from participating in classroom discussion.

\begin{tabular}{ccccccc}
\hline \multicolumn{2}{c}{ Options } & Never & Rarely & Occasionally & Very Often & Always \\
\hline Country & UAE & $29.0 \%$ & $34.4 \%$ & $28.0 \%$ & $7.5 \%$ & $1.1 \%$ \\
& SA & $18.0 \%$ & $45.1 \%$ & $27.9 \%$ & $3.3 \%$ & $5.7 \%$ \\
& UAE \& SA & $23.0 \%$ & $41.7 \%$ & $27.2 \%$ & $4.7 \%$ & $3.4 \%$ \\
\hline
\end{tabular}




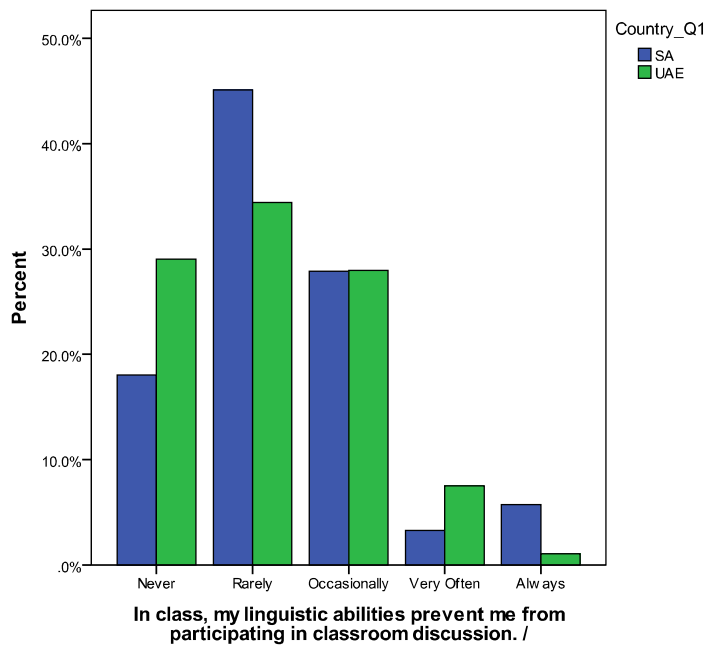

Figure 2. Item 2 (Linguistic abilities and classroom participation) Responses by Percentage

Table 6

Independent t-test results for item 2(Linguistic abilities and classroom participation)

\begin{tabular}{|c|c|c|c|c|c|c|c|}
\hline Item & Country & $n$ & Mean & $S D$ & $t$ & $p$ & Cohen's d \\
\hline In class, linguistic deficits prevent & SA & 122 & 2.34 & 1.01 & 1.20 & 0.23 & na \\
\hline $\begin{array}{l}\text { me from participating in } \\
\text { classroom discussion. }\end{array}$ & UAE & 93 & 2.17 & .97 & & & \\
\hline
\end{tabular}

Several other Likert-scale responses obtained further data for classroom socialization. In terms of comfort level in participating in classroom activities, such as the large and small group discussions, the results shown $26.7 \%$ of Emirati students are "less comfortable" participating in large group discussions. However, $36.0 \%$ of the Emirati respondents are "very comfortable" participating in small group discussions. Similarly, the results show $29.2 \%$ of Saudi students are "less comfortable" participating in large group discussion; but $34.2 \%$ of Saudi respondents are "very comfortable" participating in small group discussions. This implies some Emirati and Saudi students' perceptions of participating in group discussions are a challenging classroom activity. (See Tables 7, 8, 9, and 10)

Table 7

Item 3 (Large group discussion) Responses by Percentage In class, I am most comfortable doing... - Large group discussion

\begin{tabular}{ccccccccc}
\hline & \multicolumn{1}{c}{ Option } & $\begin{array}{c}\text { Very } \\
\text { Comfortable }\end{array}$ & Comfortable & $\begin{array}{c}\text { Less } \\
\text { Comfortable }\end{array}$ & Uncomfortable & $\begin{array}{c}\text { Sometimes } \\
\text { Uncomfortable }\end{array}$ & $\begin{array}{c}\text { Very } \\
\text { Uncomfortable }\end{array}$ & $\begin{array}{c}\text { It Does } \\
\text { Not } \\
\text { Matter }\end{array}$ \\
\hline Country & UAE & $10.0 \%$ & $24.4 \%$ & $26.7 \%$ & $14.4 \%$ & $10.0 \%$ & $12.2 \%$ & $2.2 \%$ \\
& SA & $17.5 \%$ & $22.5 \%$ & $29.2 \%$ & $13.3 \%$ & $8.3 \%$ & $5.8 \%$ & $3.3 \%$ \\
& UAE \& SA & $14.0 \%$ & $24.0 \%$ & $27.1 \%$ & $13.1 \%$ & $9.6 \%$ & $9.2 \%$ & $3.1 \%$ \\
\hline
\end{tabular}

\section{Table 8}

Item 4 (Small group discussion) Responses by Percentage

\begin{tabular}{lcccccccc}
\hline \multicolumn{1}{l}{ In class, I am most comfortable doing...-Small group discussion } \\
\hline & $\begin{array}{c}\text { Very } \\
\text { Comfortable }\end{array}$ & Comfortable & $\begin{array}{c}\text { Less } \\
\text { Comfortable }\end{array}$ & Uncomfortable & $\begin{array}{c}\text { Sometimes } \\
\text { Uncomfortable }\end{array}$ & $\begin{array}{c}\text { Very } \\
\text { Uncomfortable }\end{array}$ & $\begin{array}{c}\text { It Does } \\
\text { Not } \\
\text { Matter }\end{array}$ \\
\hline Country & UAE & $36.0 \%$ & $32.6 \%$ & $6.7 \%$ & $1.1 \%$ & $9.0 \%$ & $9.0 \%$ & $5.6 \%$ \\
& SA & $34.2 \%$ & $31.7 \%$ & $13.3 \%$ & $4.2 \%$ & $3.3 \%$ & $7.5 \%$ & $5.8 \%$ \\
& UAE \& SA & $33.3 \%$ & $30.7 \%$ & $11.4 \%$ & $3.1 \%$ & $6.1 \%$ & $9.6 \%$ & $5.7 \%$ \\
\hline
\end{tabular}


Table 9

Independent T- test Results for Items 3 (Large group discussion) and 4 (Small group discussion)

\begin{tabular}{lccccccc}
\hline \multicolumn{1}{c}{ Item } & Country & $n$ & Mean & $S D$ & $t$ & $p$ & Cohen's d \\
\hline In class, I am most & SA & 120 & 3.21 & 1.78 & 1.74 & .08 & na \\
$\begin{array}{l}\text { comfortable doing... - Large } \\
\text { group discussion }\end{array}$ & UAE & 90 & 3.66 & 1.93 & & & \\
$\begin{array}{l}\text { In class, I am most } \\
\text { comfortable doing... - Small }\end{array}$ & SA & 120 & 2.54 & 1.80 & .46 & .65 & na
\end{tabular}

group discussion

Note. Response scale: $1=$ Very comfortable; $2=$ Comfortable; $3=$ Less Comfortable; 4= It Does Not matter; 5= Sometimes Uncomfortable; 6= Uncomfortable; $7=$ Very Uncomfortable

\section{Table 10}

Item 5 (Presentations) Responses by Percentage

\begin{tabular}{lccccccc}
\hline \multicolumn{2}{l}{ In class, I am most comfortable doing...-Presentations } & & & \\
\hline \multicolumn{1}{c}{ Country } & $\begin{array}{c}\text { Very } \\
\text { Comfortable }\end{array}$ & Comfortable & $\begin{array}{c}\text { Less } \\
\text { Comfortable }\end{array}$ & Uncomfortable & $\begin{array}{c}\text { Sometimes } \\
\text { Uncomfortable }\end{array}$ & $\begin{array}{c}\text { Very } \\
\text { Uncomfortable }\end{array}$ & $\begin{array}{c}\text { It Does Not } \\
\text { Matter }\end{array}$ \\
\hline UAE & $17.8 \%$ & $22.2 \%$ & $24.4 \%$ & $15.6 \%$ & $7.8 \%$ & $10.0 \%$ & $2.2 \%$ \\
SA & $15.8 \%$ & $32.5 \%$ & $22.5 \%$ & $14.2 \%$ & $10.8 \%$ & $1.7 \%$ & $2.5 \%$ \\
UAE \& SA & $21.6 \%$ & $26.0 \%$ & $20.7 \%$ & $14.1 \%$ & $8.4 \%$ & $6.2 \%$ & $3.1 \%$ \\
\hline
\end{tabular}

This section presents some of the interview analysis to its themes based on the research questions. Research Question 1: What participation challenges do Emirati and Saudi students face at US universities?

\subsection{Speaking and Presentation Challenges}

Some Saudi students' claimed linguistic difficulties prevent them from participating in class. Khalifah commented:

At the beginning, I was silent in the classroom in the language preparation program. I was afraid to talk. My linguistics ability was zero. I was shy, afraid to talk and make mistakes because others may laugh.

Khalifah expressed worry for his first presentation. After his academic socialization process, doing a presentation became easy. Khalifah commented:

My first presentation, I was worried. It is not because of lack of my knowledge. I was scared because of the audience. I felt it was difficult. But after that, I am fine with doing presentations

\subsection{Lack of Cultural Knowledge}

Jokes in a new language are difficult to understand jokes because students have to learn the needed vocabulary in order to appreciate the humor and the culture. Emirati and Saudi students find difficulty following some classroom discussions and socializing with American students because they miss the meanings of the American jokes because of the language barrier or the meaning of certain words in the context that the word or phrase is being used. Zayed commented specifically about such situations.

Sometimes American students tell jokes in classrooms but we do not understand the jokes because it is cultural. It is like the Emirati cultural jokes which I understand. There are some issues related to American traditions which I do not understand that complicates understanding the classroom discussions.

Sheikha also commented regarding the difficulty of really understanding certain conversations because of the 
Al Murshidi, G.

cultural context.

When American students tell a joke and laugh, I do not laugh because I do not understand the meaning of the metaphor of the phrases. I do not understand their idioms but now, I understand some of their jokes.

\subsection{Communication Challenges with American Students}

Different communication skills might influence students' relationships especially if they come from different cultures. For instance, Emirati student "Zayed" experienced ignorance from American students and Saudi student "Khalifah" emphasized the American students' preference to work with their American peers. Zayed commented:

I am talkative in the classroom. Some American students do not like to communicate with us.

Other American students just communicate with us in our group work. They do not like to know us.

Zayed wonders whether the American students' have a fear regarding communicating with international students in general.

American students have no rapport with us. They may not be used to communicate with us or they may be afraid of us. I see American students communicate effectively with each other. American students do not communicate well with international students.

Khalifah's observation relates to American students' preferences for working in class assignments with fellow American students.

American students prefer to work with each other. I do not know the reason. Also, some of them work part-time which complicates our meeting to do our work.

\subsection{Arabs' Negative Influence on Their Peers}

Learning English is one of Emirati and Saudi students' main goals when coming to the US The existence of Arabs surrounding these students' increases opportunities for practicing English, especially in language preparation programs especially if the Arabs students are mocking on each other. That is when we make mistakes we should be working with each other to learn English and improve our communications in English. However, that does not necessarily happen. Hassan indicated this opportunity may not be utilized.

Our problem is here we have many Arabs so we speak Arabic most the time

Khalifah commented that sometimes fellow Arab students are not helpful at all.

When I made mistakes, Arabs students laugh at me. Therefore, I was shy to talk in the classroom.

Once, I had a fight with an Arab student because he was laughing at me. I asked him: "Why are you laughing? "He did not give me any response

\subsection{Female students' communication challenges with male students}

Conservative cultural attitudes lead Gulf region female students to avoid any kind of communication with men. At one time, female and male Emirati and Saudi students studied in separate schools and classes in their native countries. The communication between women and men is very limited even in work. Moving to American mixed classes triggers communication difficulties especially for female students. Comments from male and female Emirati students explaining their attitudes regarding this issue are. Zayed commented:

In my classes, I have an Emirati female student who I work with .There are some other Emirati 
Participation challenges of Emirati and Saudi students at US universities

female students who avoid talking with male Emirati or gulf region students even if they are in same classes.

Hoor mentioned how she attempts to avoid interacting with all male classmates regardless whether they are from the Gulf or whether they are American males.

I try to avoid male students in our discussions in our classes. It does not matter if the male students are American or Arabs. I noticed that male students like to talk, and I want to focus in the class. In some cases, I will choose to speak with American male students instead of male students from the Gulf region because I heard a lot that male students form the Gulf region talk about the girls. I know that I do not do something wrong. I respect myself. However, male students still talk about girls.

The following section presents some of the interview analysis to its themes based on the second research question. Research Question 2: How do Emirati and Saudi students cope with these participation challenges to succeed in the US universities?

\subsection{The Ease of Speaking and Presentations}

Hassan described in detail his past experiences doing several presentations in Saudi Arabian universities; these prepared him adequately for presentation in US universities. He has confidence present papers before an audience, despite grammatical mistakes, which he does not consider a problem. The most important characteristic is to have a good content.

I do presentations. Every semester, students have to do two or three presentations at the Intensive English Communication Program (IECP). I do not have a problem with doing presentation. When I was in my bachelor's degree program, I did many presentations. For instance, in my bachelor's degree, I did two presentations. Of course, it is in front of professors and they ask questions while I am presenting. In my master's degree program, each semester, I have to do presentation, I read a research paper and discuss the paper to find out the weakness and strengths in the research paper and discuss them with the professor. Some professors and students attend the discussion. At the end of each semester, we have a progress report for the master's thesis to report what we have done. At presenting the final results, it is open to the public and some professors from the college or the department or the university, attend the presentation. Al hemdellah, I did not have any issue with doing presentations. My presentation in Saudi Arabian universities during my master's and bachelor's degree programs were in Arabic. Here, I have to present in English. The language is different but the basics in giving presentations are similar such as standing in front of people and being confident. It will be no issue even if I make some linguistics mistakes once or twice, it will be no problem. I practice before my presentation. I learned this from my own experience to practice before doing anything.

Two female students emphasized the easiness of doing presentations. Hoor commented:

I present the results of my experiments. Presentation is very easy for me.

Sheikha commented:

I prefer presentation and I am not shy to stand and speak up.

\subsection{Classroom Participation and Socialization}

The Emirati and Saudi female students expressed their experiences in communicating with their classmates. Influences could include lack of knowledge, class size, or gender. Hoor commented: 
When I do not know the answer for a question, I will ask some students next to me in the class but if I know the answer, I will not bother to ask and I will focus to the teacher's discussion

Sheikha commented:

My classes are big and include 700 students. I communicate with Gulf region male students rarely for academic help. I do not find any difference to work with American or Gulf region students.

Hassan described his participation experiences in class and emphasized his ignorance of his mistakes. He noticed his native language interferes with his speech.

I do not have a problem in participating. If I make mistakes, I try to repeat and say it again. I have experience of saying some Arabic words instead of English. I did that a lot. During my English speech, suddenly, I say an Arabic word. I think it is normal.

Khalifah expressed his adjustment for participating in class and overcoming shyness:

After two months in the language preparation program, I was trying to decrease my shyness and trying to speak. Then, I started to learn.

\subsection{Socialization with American students}

Sheikha described her adaptation experiences in socializing with American students. She commented:

The first time when I communicated with American students, I felt expatriated but now I am more comfortable to work with American students because I started to understand their communication style. American students considered me shy even though everyone knows that I am not shy.

Classroom socialization strengthens Zayed's relationship with American students outside the classroom, as he described:

I was walking on campus. Three American girls who were my classmates saw me and said, "Hi," and asked me about my classes. These students know me because I helped them when they needed some clarifications for some assignments

Zayed added:

In small classes, we usually communicate with American students and know them well.

The dormitory is a way of strengthening the relationship between Gulf region's students and American students, as Zayed commented:

Some of my friends told me that if I stayed at the dorm, American students might communicate well with us.

\subsection{Teachers' Socialization and Support}

Khaled expressed ease for communicating with professors in English through speaking with the assistance of body language:

If a professor is in front of me, I can explain to him a little bit what I want to say with some grammatical mistakes, which is acceptable. The professor will still understand me.

Teachers support the Emirati and Saudi students' participation, writing papers, and examinations. Khalifah 
commented:

My teachers were supporting me. They encourage me to be relaxed when speaking. They told me the important strategy to learn English is continually practicing.

\section{Discussion and conclusions}

The major findings of this study allow discussion of participation, presentation and speaking challenges. Four items from the questionnaire examine participation challenges of Emirati and Saudi students in their classrooms: The majority of Emirati students and Saudi students indicated that their linguistics deficits "rarely" prevent them from classroom participation. Emirati students "rarely" feel that native English speaking students are more competent than they are in classes. However, Saudi students "occasionally" feel that native English speaking students are more competent than they are in classes. Emirati and Saudi students are "less comfortable" participating in large group discussions, and "comfortable" participating in small group discussion in classes. Emirati and Saudi students are "less comfortable" completing presentations assignments.

However, interview results show more stories of the Emirati and Saudi students experiences in depth that explain some of the questionnaire results and some of its contradictions. Researchers found several factors that influence the cultural adjustment of international students. Some of these factors are language differences and skills (Klineberg \& Hull, 1979). A Saudi student, Khalifah, indicated his experience with silence upon arriving in the US language preparation program due to language differences. He is fluent in his native language "Arabic" and trying to improve his English proficiency. Adjustment required time to adopt the speaking language: "At the beginning, I was silent in the classroom in the language preparation program. I was afraid to talk. My linguistic ability was zero. I was shy, afraid to talk and make mistakes because others may laugh". However, the survey results indicate that the majority of Emirati students and Saudi students stated that their linguistic deficits "rarely" prevent them from classroom participation.

Yang and Clum (1994) stated that among many factors that affect international students' adjustments, language proficiency is the most important detriment. Barrat and Huba (as cited in Malkinckrodt et al., 2008) found that a high level of language proficiency leads to international students' academic success and adjustment to the host culture. This proficiency enhances international students' performances in classes and feelings of comfort when participating in discussions. As Zayed, an Emirati student indicated, his high English language proficiency facilitated his academic success in engineering studies in Pennsylvania State University as a result of good preparation in the UAE higher technology school.

The literature suggested some dimensions and variables that influence international students' adjustment problems. Notably, perhaps, of the most important are language difficulties (Klineberg and Hull, 1979). The current study shows some contradictions in the Emirati and Saudi students' responses. The survey results indicated that the majority of Emirati students and Saudi students stated that their linguistics deficits "rarely" prevent them from classroom participation. However, some Emirati and Saudi interviewees expressed their linguistic challenges in their presentations that affect their language socialization process in their classrooms. Some Saudi students' claimed linguistic difficulties prevent them from participating in class. As Khalifah commented: "At the beginning, I was silent in the classroom in the language preparation program. I was afraid to talk. My linguistics ability was zero. I was shy, afraid to talk and make mistakes because others may laugh".

Language socialization is significant theoretical perspective for the current research that describes the use of language to mediate social interaction in academics (e.g., Bizzell, 1992; Eckert and McConnell-Ginet, 1998; Lave and Wenger, 1991, 1998). Khaled, an Emirati student, expressed his use of body language with words to communicate with his professor: "If a professor is in front of me, I can explain to him a little bit what I want to say with some grammatical mistakes, which is acceptable. The professor will still understand me."

Researchers found several factors that influence the cultural adjustment of international students. The most 
important factor is social interactions within the host country (Church, 1982). Zayed, an Emirati student, indicated that his socialization with American students in his courses strengthens his relationship with Americans outside the classroom and ease his adjustment to the culture: "I was walking on campus. Three American girls who were my classmates saw me and said, 'Hi', and asked me about my classes". These students know me because I helped them when they needed some clarifications in some assignments. Teachers' support is crucial in international students' socialization and attrition (Gardner, 2010). Khalifah, a Saudi student, expressed his teachers' support: "My teachers were supporting me".

The study implies that Emirati and Saudi students' sponsors should prepare students for American culture and US universities to enhance success academically and socially. Sponsors should prepare students to learn new skills and adjust to the educational system of the American universities, which is different from that in their native countries.

Institutions for higher learning must establish environments, which allow Emirati and Saudi students to become comfortable and engender a sense of belonging upon arrival at US universities. In addition, an organized, structured session with Emirati and Saudi students should provide information that outlines the specific services available to international students such as speaking centers and learning centers, etc. Emirati and Saudi students should be encouraged to take advantage of success enhancing services. US universities need to hire more Arab professors and teaching assistants to support the Emirati and Saudi students in their studies because they will understand the language and culture.

Emirati and Saudi students should adopt involvement in college exploration and selection processes to become more comfortable with their transitions to college. With this kind of atmosphere, institutions can address particular challenges arising from students' backgrounds. Emirati and Saudi students need more coursework in academic speaking to prepare them for their academic disciplines. Emirati and Saudi students in the language preparation program and US universities should be aware that making mistakes is part of their learning. They should try to participate in the classroom.

\section{References:}

Al-Ahaydib, M. (1986). Teaching English as a foreign language in the schools of Saudi Arabia. Unpublished Doctoral dissertation, University of Kansas, Lawrence.

Staff writer (2002). Ministry eyes ways to utilize newly hired English teachers. Retrieved October 19, 2012, from http://www.arabnews.com/node/223593

Abbad, A. (1988). An analysis of communicative competence features in English texts in Yemen Arab Republic. Unpublished Doctoral dissertation, University of Illinois at Urban -Champaign.

Abdul Haq, F. (1982). An analysis of syntactic errors in the composition of Jordanian Secondary students. Unpublished Masteral thesis, Yarmouk University, Jordan.

Badri, A. (1998). School social work and school effectiveness in the Gulf States. School Psychology International, 19(2), 121-134. http://dx.doi.org/10.1177/0143034398192002

Belcher, D. (1994). The apprenticeship approach to advanced academic literacy: Graduate students and their mentors. English for Specific Purposes, 13, 23-34. http://dx.doi.org/10.1016/0889-4906(94)90022-1

Canagarajah, S. (2002). Multilingual writers and the academic community: Towards a critical relationship. Journal of English for Academic Purposes, 1, 29-44. http://dx.doi.org/10.1016/S1475-1585(02)00007-3

Casanave, C. P. (1995). Locating interactions: Constructing contexts for composing in a graduate sociology program. In Belcher, D., \& Brain, G. (Eds.), Academic writing in a second language. Essays on research \& pedagogy (pp. 83-110). Norwood, NJ: Ablex.

Casanave, C. P. (2002). Writing games: multicultural case studies of academic literacy practices in higher education. Mahwah, NJ: Lawrence Erlbaum Associates.

Duff, P. A. (2003). New directions in second language socialization research. Korean Journal of English Language and Linguistics, 3, 309-339. 
Participation challenges of Emirati and Saudi students at US universities

Duff, P. A. (in press). Language socialization into academic discourse communities. Annual Review of Applied Linguistics.

Gaad, E., Arif, M., \& Scott, F. (2006). Systems analysis of the UAE education system. International Journal of Educational Management, 20(4), 291-303. http://dx.doi.org/10.1108/09513540610665405

Gable, R. K., \& Wolf, M. B. (1993). Instrument development in the affective domain measuring attitudes and values in corporate and school settings (2nd ed.). Dordrecht: Springer Netherlands. http://dx.doi.org/10.1007/978-94-011-1400-4

Harrison, W., \& Prator, C. H. (1975). English-language policy survey of Jordan: A case study in language planning. Arlington, Va.: Center for Applied Linguistics.

Hirvela, A., \& Belcher, D. (2001). Coming back to voice. The multiple voices and identities of mature multilingual writers. Journal of Second Language Writing, 10, 83-106. http://dx.doi.org/10.1016/S1060-3743(00)00038-2

Information Office of the Royal Embassy of Saudi Arabia in Washington, DC. (2012).The History of Saudi Arabia. Retrieved June 20, 2012, from http://www.saudiembassy.net/about/country-information/history.aspx

Ivanic, R. (1998). Writing and identity: The discursive construction of identity in academic writing. Amsterdam: John Benjamins. http://dx.doi.org/10.1075/swll.5

Ivanic, R., \& Camps, D. (2001). I am how I sound: Voice as self-representation in L2 writing. Journal of Second Language Writing, 10(1-2), 3-33. http://dx.doi.org/10.1016/S1060-3743(01)00034-0

Kagan, H., \& Cohen, J. (1990). Cultural adjustment of international students. Psychological Science, 1(2), 133-137. http://dx.doi.org/10.1111/j.1467-9280.1990.tb00082.x

Kanno, Y. (2003). Negotiating bilingual and bicultural identities Japanese returnees between two worlds. Mahwah: Lawrence Erlbaum Associates.

Kasper, G. (1997). "A" stands for acquisition: A response to Firth and Wegner. The Modern language Journal, 81(3), 307-312.

Klineberg, O., \& Hull, W. F., IV. (1979). At a foreign university: An international study of adaptation and coping. New York: Praeger.

Lave, J., \& Wenger, E. (1991). Situated learning: legitimate peripheral participation. Cambridge, England: Cambridge University Press. http://dx.doi.org/10.1017/CBO9780511815355

Merriam, S. B. (2002). The nature of qualitative inquiry. In Merriam, S., \& Associates (Eds.). Qualitative research in practice (pp. 3-33). San Francisco, CA: Jossey-Bass.

Morita, N. (2000). Discourse socialization through oral classroom activities in a TESL graduate program. TESOL Quarterly, 34, 279-310. http://dx.doi.org/10.2307/3587953

Naggar Gaad, E. E. (2001). Educating children with down's syndrome In The United Arab Emirates. British Journal of Special Education, 28(4), 195-203. http://dx.doi.org/10.1111/1467-8527.t01-1-00225

Prior, P. (1995). Redefining the task: An ethnographic examination of writing and response in graduate seminars. In Belcher, D. \& Brain, G. (Eds.), Academic writing in a second language: Essays on research \& pedagogy (pp. 26-43). Norwood, NJ: Ablex.

Rababah, G. (2002). Communication Problems Facing Arab Learners of English. Journal of Language and Learning, 3(1), 180-197.

Saudi Arabia Cultural mission to the US. (2012). Background educational system in Saudi Arabia. Retrieved October 19, 2012 from http://www.sacm.org/Education.aspx

Syed, Z. (2003). The sociocultural context of English language teaching in the Gulf. TESOL Quarterly, 37(2), 337-341. http://dx.doi.org/10.2307/3588508

Shaw, K., Badri, A., \& Hukul, A. (1995). Management concerns in United Arab Emirates state schools. International Journal of Educational Management, 9(4), 8-13. http://dx.doi.org/10.1108/09513549510088381

Sheshsha, J. (1982). The qualifications of a competent teacher of English in Saudi Arabia. Unpublished Doctoral dissertation, Indiana University, Bloomington.

Stone, E. F. (1978). Research methods in organizational behavior. Santa Monica: Goodyear Pub. Co.. 
Al Murshidi, G.

Trochim, W., \& Donnelly, J. (2007). The research methods knowledge base (3rd ed.) Mason, OH: Atomic Dog Publishing.

Vijver, F. J., \& Leung, K. (1997). Methods and data analysis for cross-cultural research. Thousand Oaks, CA: Sage.

Yang, B., \& Clum, G. A. (1995). Measures of life stress and social support specific to an Asian student population. Journal of Psychopathology and Behavioral Assessment, 17(1), 51-67. http://dx.doi.org/10.1007/BF02229203

Zaid, M. A. (1993). Comprehensive analysis of the current system of teaching English as a foreign language in the Saudi Arabian intermediate schools. Unpublished Doctoral dissertation, University of Colorado, Boulder. 